\title{
流域における水循環の把握と水資源の配分に関する研究

\author{
A STUDY ON WATER BUDGET AND \\ WATER RESOURCES ALLOCATION IN A BASIN
}

\author{
三好逸二*・関 正 和**.吉川勝秀***・朴 栄 秀**** \\ By Ituji MIYOSHI, Masakazu SEKI, Katsuhide YOSHIKAWA \\ and Eishı BOKU
}

\section{1. 序}

水資源をめぐる諸問題の深刻化は，新たな水資源の開 発やその配分・利用形態などに対する種々の観点からの 見直しを促しつつある. 従来の水資源の配分・利用に関 する計画は, ある限られた利水部門を対象にして立案さ れたものが多い，ところが，水は流域を流れ去る間に， 家庭・工業・農業・業務といった利水部門や, 河川・地 下等の間で複雑にやりとりされる。したがって, 限られ た水資源を流域内で合理的に配分・利用するためには， 特定の利水部門のみを対象とした計画では不十分であ り，流域全体を包含する水システムを考える必要があ る. また，水資源の配分を考察する際には，水に対する 地域社会のさまざまな要望に十分留意すべきである.

水資源の配分・管理計画を立案する場合には，その前 提として, 流域内の水循環や水資源の配分現況が総合的 に把握されている必要がある. そして，水資源の配分計 画が実現されれば, 現在の水利用状況がどのように変化 し，それが地域社会にどのような影響を及ぼすかを推察 することが重要である、ところが，総合的な状況把握は ほとんどといってよいほどなされておらず，そのための 方法論も十分に研究されているとはいいがたい. そこ で, 本報告では, まず, 流域内の水収支を総合的に把握 する方法を提案する. 次に，この方法に基づいた水資源 の配分・利用モデルを定式化し, 流域内の水資源を総合 的かつ経済・社会・環境等の多角的な観点から管理する 方法を考察する.ささらに, 提案した流域内の水収支把握 方法と水資源の配分・利用モデルを大和川流域の奈良盆

\footnotetext{
* 正会員 工修 建設省土木研究所企画部システム㭷建設専 門官

** 正会員 工修 建設省土木研究所企画部システム課研究員 *** 正会員 工修 建設省土木研究所企画部システム課研究員 **** 正会員 工修 (株) 長大橋設計 センターシステム開発部 M.C
}

地に適用し，ケース・スタディを行った結果を報告す る.

\section{2. 従来の研究と本研究の基本的立場}

従来の水資源の配分・利用に関する研究は, ある特定 の利水部門（たとえば，都市用水あるいは農業用水）を 対象にして行われたものが多い亩 9). 日本における水資 源の配分に関する先駆的な研究としては, 合田ら ${ }^{1)}$ の研 究がある. 合田らは工業用水の最適配分問題を線形計画 法で取り扱い，問題を定式化する際に導入される諸係数 が最適解に及ぼす影響等について考察を行っている. 春

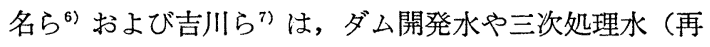
利用水）等の都市への配分問題を同じく線形計画法で定 式化し, 最適解を求める際に分解原理を用いると, 種々 の計画間の調整過程を理解するうえで都合がよいとして いる. また, 吉川ら ${ }^{8)}$ は建設費・維持管理費や水質を厳 密に考慮する際に生じる非線形問題についても考察して いる. 外国の研究においても, 線形計画法で定式化を行 ったものが最も多く2) 4),10),12), ネットワーク手法 ${ }^{11)}$ や動 的画法5を用いたものもあるが，全般的にある限られた 利水部門を対象としているものが多い.

流域全体の水管理といら観点から, 従来の水資源の配 分・利用に関寸る研究をながめてみると, 次のような問 題点が浮かびあがる.

(i ） 農業用水の還元利用や都市用水の開放系 ${ }^{13)}$ とし ての再利用など, 流域内でくり返し利用される水（流域 の水循環）の取り扱いが十分でない.

（ii）家庭・工業・農業・河川・地下（水）等が複雑 に絡みあって水配分ネットワークを構成しており，その 間の水の流動が流下・浸透・蒸発散等の 自然の法則と 種々の社会・経済的関係の双方によって規定されている ことに関する考察が不足している.

（iii）水資源に対する地域社会の要望を, 経済・社 
会・環境等の多角的な観点からとらえ, それを流域の水 配分計画に反映させる努力が不足している.

これらの問題を解明するためには，今までのようにあ る限られた利水部門を対象とする取り扱いでは不十分で あり，流域全体を包含した総合的な水循環システムを考 えることが重要である.すなわち，あらゆる利用水，排 水および自然水を含めた流域内の水収支を総合的に取り 扱う必要がある．また，水資源の配分計画を立案する際 には，水資源が地域社会で果す役割を十分に認識してお くことも重要である.

本論文では, 上述のことを念頭におき, 流域内の水資 源の配分問題を考察する方法を提示する. 従来の研究に おいては，水資源の配分方法について多くの方法論が提 示されているにもかかわらず，あらゆる水資源問題の検 討の前提となる総合的な状況把握に対する方法論は, 必 ずしも十分に開発されているとはいいがたい.そこで, まず，その方法として一覧表（「水資源連関表」）による 分析法を提案する.この水資源連関表は, 経済学の分野 で提案された地域間産業連関表と類似の構造をもつもの であり，流域内の各地区間でやりとりされる水量と各地 区内の水資源に関連する要素間(後述の流域構成要素間) でやりとりされる水量を体系的に示すことができる.こ れにより流域における水循環と水資源の配分状況が総合 的に把握される.

次に, 水資源連関表に基ついて, 流域内の水資源の配 分問題を定式化する. 本研究でも, 問題の性格, 精度, 解法の簡便さなどを考慮して, 線形計画法を用いること にする.ただし，線形化により生じる問題点は，ケー ス・スタディの際に感度分析等により明確にし, 諸係数 の設定には十分注意を払うことにする．定式化にあたっ ては, 物理的な条件として水量の連続条件と運動に関す る条件を制約条件として含め，水資源に対する地域社会 の要望を, 各種の社会的制約条件および目的関数として
記述し，多角的な検討を行う.

以上で述べた方法を大和川流域の奈良盆地に適用し， ケース・スタディを行った. その内容は次のようなもの である。

（i）水資源連関表による奈良盆地の水循環と水資源 の配分現況の把握

（ii） 水資源の適正配分に関するシミニレーション

（iii）（i）（ii）をもとにした水資源をめぐる諸問題の 検討

（iv）提案した方法論の（i)，(ii)，(iii）をもとにした 検討

本研究は, 地表水・地下水および大気中の水も含めた 流域の水循環を取り扱っており, 現状の水資源の配分 利用形態の見直しや広域的な水管理などには有益である と考える.

\section{3. 流域における水循環と水資源の配分・利用 状況を体系的に表示する方法の提案}

ここでは, 流域における水循環と水資源の配分・利用 状況を体系的に表示する方法を提案する.

\section{（1）流域構成要素とその特質}

水資源の配分・利用には, 河川 -上水道・下水道・家 庭・工業等の特質を異にする要素が関連している. 各要 素は, 水を輸送する機能, 利用する機能, 污濁負荷を発 生させる機能等の諸機能のうち一つまたは複数をそなえ ている.これらの要素を「流域構成要素」とよび,ここ では河川・地下・上水道・家庭・業務・工業・農業・下 水道・流域の 9 要素を取り上げる. それぞれの要素がも つ機能を 表一1 のようにとらえることにする。

流域はいくつかの地区から構成されており, 各地区は それぞれこれら 9 要素を含むものとしてとらえられてお

\section{表一1 流域構 成 要素とその機能}

\begin{tabular}{|c|c|c|c|c|c|c|c|}
\hline $\begin{array}{l}\text { 流域構成 } \\
\text { 藻紧 }\end{array}$ & 概 要 機能・特置 & $\begin{array}{l}\text { 地区間 } \\
\text { 輸送機能后 } \\
\text { ちつ要 }\end{array}$ & 水利用装素 & $\begin{array}{l}\text { 降水曼水 } \\
\text { 機能を方主 } \\
\text { 装 }\end{array}$ & 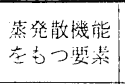 & 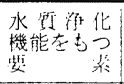 & 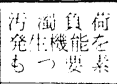 \\
\hline 河川 & 湖治在含方 & 0 & & $0^{* 1}$ & $0 * 1$ & $\partial * 2$ & \\
\hline 地下（水） & 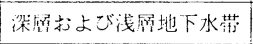 & 0 & & & & $O^{* 2}$ & \\
\hline 上水 道 & 取水・学水・浄水・能水 & 0 & & & & () & \\
\hline 涏 & 宅 & & $\bigcirc$ & & 0 & $0^{* 3}$ & $\cdots$ \\
\hline 务 & 主上して 3 次㝻棠 & & 0 & & $\bigcirc$ & $O^{* 3}$ & 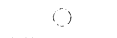 \\
\hline 工 業 & 煋 & & $\bigcirc$ & & 0 & $O^{* 3}$ & 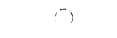 \\
\hline 業 & 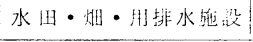 & 0 & 0 & $O$ & 0 & $0 * 2$ & () \\
\hline 下水 道 & 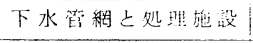 & 0 & & & & 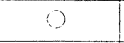 & \\
\hline 域 & 䄀地以外の地表酒 & & & 0 & () & $0^{* 2}$ & \\
\hline (it) $\begin{aligned} & * 1 \\
& * 2 \\
& * 3\end{aligned}$ & 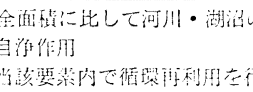 & つ晒程が小さい & 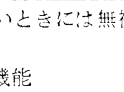 & 县文万 & & & \\
\hline
\end{tabular}


り, 流域内の水は, これら 9 要素の中のどれかに必ず含 まれる.流域内の各地区内における水のやりとりはこれ ら 9 要素相互間で行われ, 各地区間の水のやりとりは河 川・地下 · 上水道 $\cdot$ 農業 (用排水施設) ・ 下水道の水輸送 機能をもつ 5 要素を介して行われる. 降水や蒸発散等の 系外との水の受けわたしは, 降水受水機能をもつ要素お よび蒸発散機能をもつ要素を介して行われることにな る.なお, 流域構成要素をさらに細かくあるいは大まか に分類することはもちろん可能であり, 以下の議論はそ のような場合についても同様に成立する.

\section{（2）水資源連関表}

流域内の水は, 各要素間・各地区間でさまざまな形態 でやりとりされている. このような水のやりとりを表示 する方法として，表一2 に示すような一覧表(「水資源 連関表」）を提案する。これは, 概念的には地域間産業 連関表と似ており, 左端にどの地区のどの要素から水が 流入しているのか, 上端にどの地区のどの要素へ流れて 行くのかを示している.したがって，表一2に拄ける $\mathbf{A}$ の部分は, 地区 1 の内部における各要素間の水の受けわ たし量を示している.また， $\mathrm{B}$ の部分は地区 1 から地 区 2 一輸送される水量を示し, $\mathbf{C}$ の部分は地区 1 から 系外一の水量, すなわち, 対象としている地域外一の流 出および空中へ蒸発散する量を示している. 一方, $\mathrm{D} の$ 部分は地区 2 から地区 1 一輸送される水量を示し, $\mathbf{G}$ の部分は系外から地区 1 一の水量, 寸なわち, 分析の 対象としている地域外からの流入量および降水量を示し ている.

\section{表一2 水資源連 関 表}

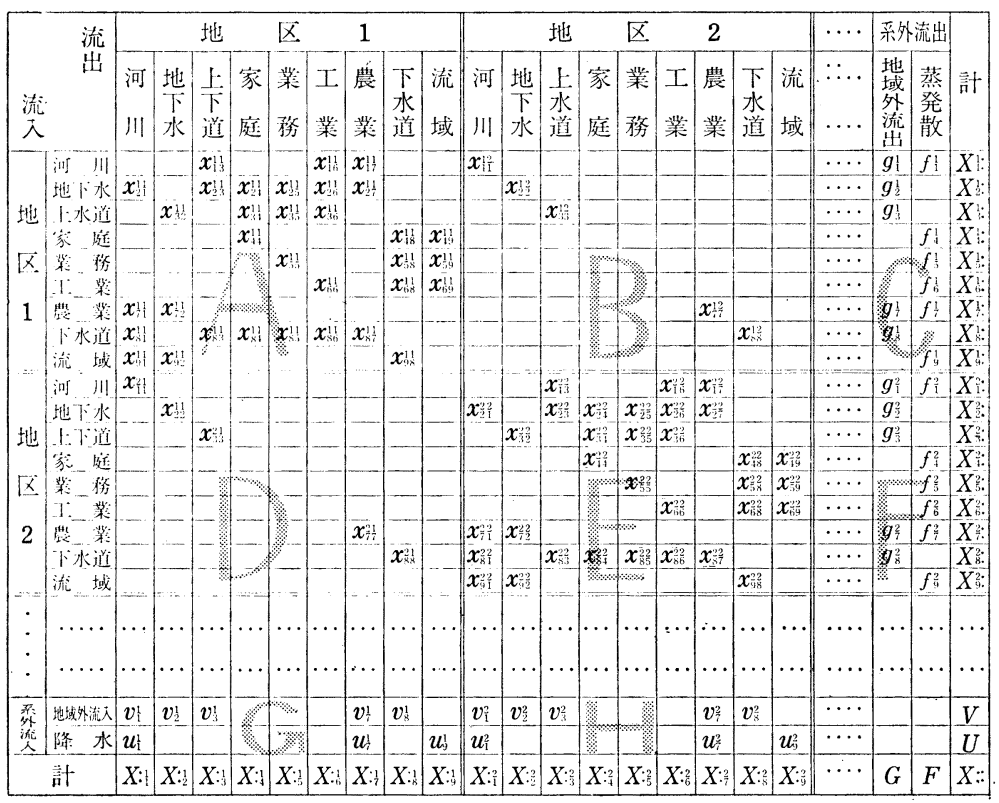

水の受けわたしは, 水資源連関表の全マス目で生じる わけではなく, その可能性のあるマス目は限定されてい る. 表一2 では, 後述するケース・スタディで水の受け わたしがないと考えられるマス目を空白にした. 同表よ りわかるように，地区内の水のやりとりを示す $\mathbf{A}, \mathbf{E}, \cdots$ の対角部分は同様のパターンをしており, 地区閒の水の やりとりを示す $\mathbf{B}, \mathbf{D}, \cdots$ の部分は水輸送機能をもつ要 素の対角成分のみが值をもつ可能性がある. また, 対象 流域外との水のやりとりを示す $\mathbf{C}, \mathbf{F}, \cdots$ と $\mathbf{G}, \mathbf{H}, \cdots$ の 部分は, 水輸送機能をもつ要素, 蒸発散機能をもつ要素 および降水受水機能をもつ要素のみが值をもつ可能性が ある。

後の理論展開の便宜のために, 次のように記号を定め る.

$x_{i j}^{r s}: r$ 地区の $i$ 要素から $s$ 地区の $j$ 要素への 水輸送量を示す. たとえば, $x_{i j}^{r r}$ は $r$ 地区 内で $i$ 要素から $j$ 要素にわたされる（排水 ・浸透・湧水・給水等) 水量を表わす.

$g_{i}^{r}: r$ 地区から $i$ なる 水輸送要素を介して分析 しょうとしている地域の外一輸送 (導水・送 水・流下等）される水量

$f_{i}^{r}: r$ 地区の $i$ 要素から蒸発散する水量

$x_{i}^{r *}: r$ 地区の $i$ 要素から他地区や対象地域の外, 大気中一移動する水量の合計 $(r$ 地区内での 移動は除()

$X_{i}^{r}:: r$ 地区の $i$ 要素から流出・移動する水量の 合計

$v_{j}^{s}$ : 対象地域の外部から $j$ なる輸送要素を介し て $s$ 地区に輸送（導水・ 送水・流下) される水量 $u_{j}^{s}: s$ 地区の $j$ 要素に降水と して入ってくる水量

$x_{: j}^{* s}$ : 他地区, 対象地域外, 大 気中方 $s$ 地区 $j$ 要素 へ移動してくる水量の合 計 ( $s$ 地域内からの移動 は除く)

$X: s: s$ 地区の $j$ 要素に入って くる水量の合計

$V$ : 対象地域外方対象地域 内の要素に導水・送水 流下等によって入ってく る水量の合計

$U$ : 降水として対象地域内一 流入する水量の合計

$G$ : 対象地域少ら地域外几導 水・送水・流下等によ。 


\section{て出る水量の合計}

$F:$ 対象地域から蒸発散する水量の合計

このように記号を定めると次の関係式が成立する.

$$
\begin{aligned}
& x_{i}^{r *}=\sum_{\substack{s=1 \\
s \neq r}}^{n} \sum_{j=1}^{m} x_{i j}^{r s}+g_{i}^{r}+f_{i}^{r} \\
& X_{i}^{r} \cdot=\sum_{s=1}^{n} \sum_{j=1}^{m} x_{i j}^{r s}+g_{i}^{r}+f_{i}^{r} . \\
& x_{. j}^{* s}=\sum_{\substack{r=1 \\
r \neq s}}^{n} \sum_{i=1}^{m} x_{i j}^{r s}+v_{j}^{s}+u_{j}^{s} \\
& X: s=\sum_{r=1}^{n} \sum_{i=1}^{m} x_{i j}^{r s}+v_{j}^{s}+u_{j}^{s} . \\
& V=\sum_{s=1}^{n} \sum_{j=1}^{m} v_{j}^{s} \\
& U=\sum_{s=1}^{n} \sum_{j=1}^{m} u_{j}^{s} \\
& G=\sum_{r=1}^{n} \sum_{i=1}^{m} g_{i}^{r} \\
& F=\sum_{r=1}^{n} \sum_{i=1}^{m} f_{i}^{r}
\end{aligned}
$$

ここに, $n$ : 対象流域内の地区数, $m:$ 流域構成要素数.

\section{（3）水資源連関表による現状把握}

水資源連関表を用いて水循環や水資源の配分・利用現 況を把握しようとすれば，まずはじめに次の 2 つの事項 を決定しておく必要がある. 1 つは分析対象期間の決定 であり，あと 1 つ分析対象地域とその内部の地区分割 の決定である.

\section{a) 分析対象期間}

分析対象期間は分析目的に応じて決定す心゙きものであ り，後述する現状把握や適正水配分シミュレーションな どにおいて重要な意味をもってくる．分析対象期間を長 く（たとえば 1 年間）とれば，流域における巨視的かつ 平均的な水の流動が把握でき，この場合には，水量に関 する連続条件および水の運動（蒸発散・地下水の涌水・ 浸透等）に関する条件を単純な形で与えることができよ う.たとえば, 水量の連続条件式は, 分析対象期間が長 ければ, 貯留量の変化が相殺されるので, 流入量と流出 量が等しいとおいてよい(14).すなわち， $t$ 地区の $k$ 要 素について

$$
\begin{aligned}
& \sum_{s=1}^{n} \sum_{j=1}^{m} x_{k j}^{t s}+g_{k}^{t}+f_{k}^{t}=\sum_{r=1}^{n} \sum_{i=1}^{m} x_{i k}^{r t}+v_{k}^{t}+u_{k}^{t} \cdots(9) \\
& \text { i.e. } X_{k \cdot}^{t .}=X: t
\end{aligned}
$$

なる関係式が成立する，また，運動を表わす式は，後述 のように蒸発散率・涌出率・浸透率・河川水や地下水の 分流比等を用いて与えることができよう. もちろん, こ のような連続および運動条件式の単純化により分析結果 の利用範囲が限定されることはいらまでもない．たとえ ば, 渴水期における水配分計画においては, 貯留量の変
化は一つの考察対象であり，上述のような取り扱いをす るわけにはいかない. また, 揚水量が流入量に比べて大 きい地下水層を含む地域においては問題が残る.

b）分析対象地域と地区分割

分析対象地域の設定においては, その地域への流出入 量が把握しやすいような境界を選ぶ必要がある.

対象地域内の地区分割にあたっては，いくつかの点に 留意する必要がある. 1 つはデータのとりやすさであ る.上・下水道関係資料は行政区画によって収集されて いるものが多いが, 河川関係資料は水文界によって収集 されている場合が多く，資料収集上都合のよい地区分割 を行う必要がある．また，1地区の中に特性の異なる複 数の河川が含まれると困難な問題が生じる. 水資源連関 表では，1 地区内の河川は 1 個のものとして取り扱う （集中系として扱う）ことから，たとえば，水質の非常 に異なる 2 本の河川が合流することなくその地区を通っ て流下するような場合には, その下流における水質解析 汇無意味となる (図一1 参照).そのような場合には, 河 川を分離するような地区割りをすることが望ましい. 複 数河川を含む地区を考える場合には，水質および流況の 似た場所を統合すべきである. 現実の問題に対しては， 以上のことがらに注意しながら, 分析目的に応じて都合 のよい地区分割を行うことになる.

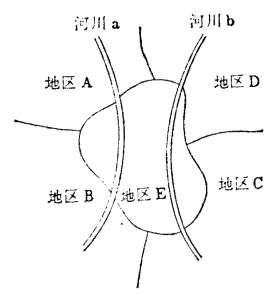

[現奏の河川䒺]

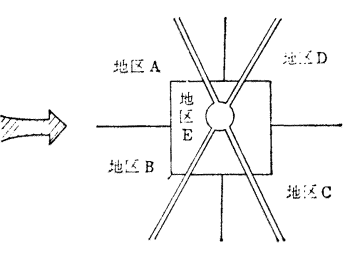

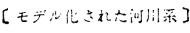

図一1 水資源連関表での河川の取り扱い

以上のような特徵をもつ水資源連関表を用いて, 流域 内を複雑にやりとりされる水の有機的な結びっきを把捯 しておくことは, 流域に㧍ける水問題を検討するうえで 重要であると考える.

\section{4. 流域における水資源の配分・利用の モデル化}

\section{（1）モデル作成の目的}

以下で述べる水資源の配分・利用モデル作成の目的流 次のようなものである.

（i）水資源の利用に関連して地域社会が望むこ上が らは多種多様である.これら種々の要求に照らして適正 な水資源の配分計画を探し出すことがモデル作成の第一 
の目的である.

（ii）水資源の配分計画案の作成にあたっては, 物理 的に実現可能であること, また, 社会・財政・環境等の 面からもそれが受け入れられることが必須の条件であ る. 以下で述べるモデルにより得られる解は, 数多くの 実現可能解のうち，ある観点からみた最適性が保証され ているにすぎない，多角的な観点から水資源計画の検討 を行うためには，どのような領域（範囲）の計画案が実 現可能であるかを把握することが重要であり，これがモ デル作成の第二の目的である.

(iii）われわれが記述（シミュレーション）できるの は，現実の世界をなんらかの形で抽象化して把握したも のでしかない.したがって，われわれが記述したものが 現実の世界をうまく説明できるか否かを検討することは きわめて重要である．同時に，目的やモデルを少し変更 させた場合にどのような結果が得られるかを把握してお くことも重要である. 種々のパラメーターや制約条件の 変更に伴う感度分析はこの一例であり, 得られた結果の 信頼性と安定性の把握 はモデル作成の第三の目的であ る.

\section{（2）線形計画法による水資源の配分・利用モデルの 定式化}

ここでは流域における水資源の配分・利用問題を，水 資源連関表に示される水のやりとり量を変数として, 線 形計画法で定式化する.

前述のように, 適正水配分計画とは, 物理・社会・経 済・環境等の面からの要求をすべて満たしたうえで実現 可能な計画が考えられる場合に，ある観点からみた最適 性が保証されているものである.したがって, 適正配分 計画を論じる場合には，必ず満たしていなければならな い制約と計画がめざすことがらが正しく記述されている
必要がある. 以下では, 分析対象期間を 1 年程度の長期 にとった場合の, 各種制約条件と目的関数について考察 する.

a) 制約条件

制約条件には大別して 2 種類のものがある．1つは物 理的な条件 (自然法則) であり, 必ず満たさなりればな らない. あと 1 つは財政, 社会・経済, 環境, 技術・施 設等の面から要求される社会的な制約条件であり, 社会 の進展とともに変化するものが多く, 不等式で表わされ るものが多い.

\section{(i) 物理的な制約条件}

(1) 水量の連続条件

水量の連続条件は線形であり, $t$ 地区 $k$ 要素につい て式 (9) あるいは式 (10) で与えられる.

(2) 運動に関する条件

水の蒸発散や流れ方を支配する条件は一般に線形では ないが，係数の決定を行った状態からのかい離が小さい 領域では，これらの条件を線形化して近似することが可 能であり，ここでは 表一3 に示すような 線形化した運 動に関する条件式を考える。

(ii) 財政面からの制約条件

(3) 建設・運営費

水資源関連施設の建設・運営費用はその地域または各 地区の可能投資額によって制約をうける，いま，建設・ 運営費が各要素間の水輸送量（送水量・浄水量・取水量 等を含む) と一単位の水を輸送（送水・浄水・取水等） するのに必要な施設の建設・運営費用との積で表わすこ とにすると, 地区 $r$ の総建設・運営費 $C^{r}$ は,

$$
\begin{aligned}
C^{r}= & \sum_{s=1}^{n} \sum_{i=1}^{m} \sum_{j=1}^{m} C_{i j}^{r s} x_{i j}^{r s}+\sum_{i=1}^{m} C_{j 0}^{r 0} g_{i}^{r} \\
& +\sum_{i=1}^{m} C_{0 i}^{0 r} v_{i}^{r} \ldots \ldots \ldots \ldots \ldots \ldots \ldots \ldots \ldots \ldots \ldots \ldots
\end{aligned}
$$

\begin{tabular}{|c|c|c|c|c|c|c|c|c|}
\hline 始 端 & 末端畒素 & 㴹動条件式 & の意味 & 始 & 端 & 末端要素 & 遇動条件式 & ๙の意涑 \\
\hline \multirow[t]{3}{*}{ 河 } & 他地域の河川 & $x_{11}^{r s}=\alpha_{11}^{r s} \cdot x_{1}^{r *}$ & 分 范 比 & 家 & 筳 & 蒸＼cjkstart発 & $f_{4}^{r}=\alpha_{4}^{r} \cdot \cdot X_{4}^{r}$ & 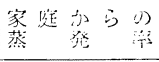 \\
\hline & 対象地域外 0 & $g_{1}^{r}=\alpha_{1}^{r g} \cdot x_{1}^{r} *$ & 分 流 比 & 業 & 務 & 蒸＼cjkstart発 & $f_{5}^{r}=\alpha_{5}^{r} \cdot X_{5}^{r}$ & 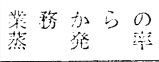 \\
\hline & 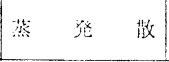 & $f_{1}^{r}=\alpha_{1}^{r f} \cdot x_{1}^{r} *$ & 留川㤎らの & I & 業 & 発 & $f_{6}^{r}=\alpha_{6}^{r} f \cdot X_{6}^{r}:$ & 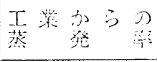 \\
\hline \multicolumn{4}{|c|}{ ただし， $\sum_{s=1}^{n} \alpha_{1 s+1}^{r s}+\alpha_{1}^{r g}+\alpha_{!}^{r f}=1$} & \multirow[t]{2}{*}{ 典 } & \multirow[t]{2}{*}{ 粟 } & 地区内の地下水 & $x_{72}^{r r}=\alpha_{7}^{r r} \cdot X_{7}^{r}$ & 地下への海澄 \\
\hline \multirow[t]{3}{*}{ 地下水 } & 地区内の酒川 & $x_{21}^{r r}=\alpha_{21}^{r r}\left(X_{2}^{r}:-\sum_{j=3}^{7} x_{2 j}^{r r}\right)$ & 地下水洒出率 & & & 発 & $f_{7}^{r}=\alpha_{7 i}^{r} \cdot X_{7}^{r}:$ & 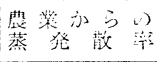 \\
\hline & 他地区の地下水 & $x_{22}^{r s}=\alpha_{22}^{r s}\left(X_{2:}^{r r}--\sum_{j=3}^{7} x_{2 j}^{r r}\right)$ & 侺地区透へ亦 & \multirow[t]{3}{*}{ 流 } & \multirow[t]{3}{*}{ 坡 } & 地区内の河川 & $x_{91}^{r r}=\alpha_{91}^{r r}\left(X_{9}^{r}:-x_{98}^{r r}\right)$ & 正接流湡落 \\
\hline & $\begin{array}{l}\text { 対象地域外の } \\
\text { 地水 }\end{array}$ & $g_{2}^{r}=\alpha_{2}^{r g}\left(X_{2}^{r}:-\sum_{j=3}^{r} x_{2 j}^{r r}\right)$ & 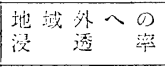 & & & 地区内の地下水 & $x_{92}^{r r}=\alpha_{92}^{r r}\left(X_{9:}^{r r}-x_{98}^{r r}\right)$ & 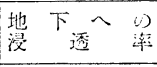 \\
\hline \multicolumn{4}{|c|}{ ただし， $\alpha_{21}^{r r}+\sum_{s=11(s+r)}^{n} \alpha_{22}^{r s}+\alpha_{2}^{r g}=1$} & & & 蒸 発 & $f_{9}^{r}=\alpha_{9}^{r f} \cdot\left(X_{9}^{r}:-x_{98}^{r r}\right)$ & 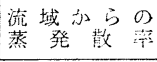 \\
\hline 上水湔 & 地风内心地下水 & $x_{32}^{r r}=\alpha_{32}^{r r} \cdot X_{3}^{r}$ & 满 水 摔 & \multicolumn{5}{|c|}{ たばし, $\alpha_{91}^{r r}+\alpha_{92}^{r r}+\alpha_{9}^{r f}=1$} \\
\hline
\end{tabular}

表一3 水の運動に関する条件式 
と書くことができる.ここに, $C_{i j}^{r s}\left(C_{i 0}^{r 0}, C_{0 i}^{o r}\right)$ は, $r(r$, $0)$ 地区 $i(i, 0)$ 要素加ら $s(0, r)$ 地区 $j(0, i)$ 要素へ 单位水量を輸送（送水・浄水・取水等）する間に必要な 年間費用であり，施設の建設費と資本回収係数との積に 年間運営費を加えたものとして与えることができる。た だし， 0 は対象地域外を示す.

さて, 各地区ごとに定められる年間可能投資額を $\bar{C}^{r}$, 対象地域について定められる年間可能投資額を $\bar{C}$ で表 わすと財政面からの制約条件は次のように表わされる.

$$
C^{r} \leqq \bar{C}^{r}(r=1, \cdots, n) \text { または } \sum_{r=1}^{n} C^{r} \leqq \bar{C}
$$

以上は建設費と運営費を一緒に考えた場合の取り扱い であるが，これらを分離して考えることもできる。すな わち，施設建設費の減価償却費用がその施設による水の 輸送量（送水量・浄水量・取水量等を含む）に比例する と考えれば, 建設費（毎年等価価格）の算定は式 (11) と同様に行える.また，施設の運営費がそれによる水の 輸送量（送水量・浄水量・取水量を含む）に比例すると 考えた場合にも同様に, 運営費の算定は式 (11) と同じ 形のものを用いることにより可能となる.そして，これ ら建設費および運営費のそれぞれに対して式 (12) と同 様な制約条件が課されることになる.

ここでは費用を水量に関して線形で表現したが，現実 には規模の経済性等によって非線形の特性を示すことが あり, 設定した係数の適用範囲については注意が必要で ある11.

(iii) 社会・経済面からの制約条件

(4) 水資源からみた収容可能人口

$r$ 地区の収容可能人口 $P^{r}$ は, 地域計画等によりあ る人数 $\bar{P}^{r}$ 以上であることが要請されることが多い.

$$
P^{r}=X: r / d_{4}^{r} \geqq \bar{P}^{r}
$$

ここに， $d_{4}^{r}$ は 1 人あたりの使用水量である.

(5) 水資源からみた生産可能額

$r$ 地区に扔ける工業・農業・業務の生産可能高も, あ
る一定額以上を求吼ることが多い， $i$ 産業において 一単位の生産を行らのに必要な水量を $d_{i}^{r}$ とすれば, 次 の制約条件式を得る.

$$
\begin{array}{r}
O_{i}^{r}=X_{i}^{r} / d_{i}^{r} \geqq \bar{O}_{i}^{r} \ldots \ldots \ldots \ldots \ldots \\
\quad(i=5,6,7, \quad r=1, \cdots, n)
\end{array}
$$

$$
\text { ここに, } \bar{O}_{i}^{r} \text { は必要生産額である. }
$$

また, 特に農業用水において見られるように制度また は慣行によってその取水量が定められている場合にはそ の取水量の上・下限值等を与える方が都合がよいことも 多い.

(6) 供給水量比

家庭・工業・業務・農業への供給水量比を定めること によりこれら相互の均衡ある発展を期すこともできる.

$$
X_{i}^{r}=\beta_{i}^{r}\left(\sum_{k=4}^{7} X_{: k}^{r}\right)\left(\begin{array}{c}
r=1, \cdots, n \\
i=4, \cdots, 7
\end{array}\right)
$$

ただし， $\sum_{i=4}^{7} \beta_{i}^{r}=1$ である.

(iv) 環境面からの制約条件

(7) 水質の規制

$r$ 地区 $i$ 要素における污濁負荷量の収支を考える（図 -2 参照). $r$ 地区 $i$ 要素に流入し, 利用された直後の 水質 (污濁負荷濃度) を $p_{i}^{r}$ とすると, これは対象地域 外から上対象地域内のほかの要素からの污濁量および発 生污濁負荷量に支配される. いま, 発生污濁負荷量が使 用水量に比例すると仮定すれば，水質浄化作用を考慮し た污濁負荷の連続式は次の上うに表わされる。

$$
\begin{aligned}
& r_{i}^{r} v_{i}^{r}+\sum_{t=1}^{n} \sum_{k=1}^{m} p_{k}^{t} e_{k}^{t} x_{k i}^{t r}+q_{i}^{r} X_{i}^{r} \text {. } \\
& =p_{i}^{r} e_{i}^{r} g_{i}^{r}+p_{i}^{r} e_{t}^{r}\left(\sum_{t=1}^{n} \sum_{k=1}^{m} x_{i k}^{r t}\right) \\
& +p_{i}^{r}\left(1-e_{t}^{r}\right)\left(\sum_{t=1}^{n} \sum_{k=1}^{m} x_{i k}^{r t}+g_{i}^{r}\right) \\
& =p_{i}^{r}\left(X_{i}^{r}:-f_{i}^{r}\right)
\end{aligned}
$$

ここに, $r_{i}^{r}:$ 対象地域外加の流入水の水質, $q_{i}^{r}:$ 発 生污濁負荷濃度, $e_{i}^{r}$ : 污濁負荷流達率 (流出污濁負荷を 流入・発生污濁負荷量の和で割った值と定義する).た

$$
\text { <流入・発生污濁負荷量＞＜流出・除却污濁負荷量 }>
$$

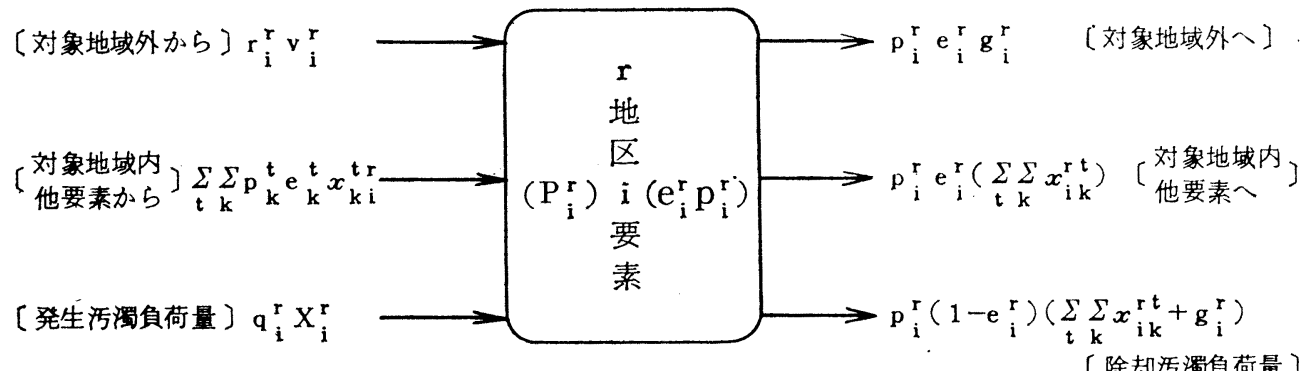


だし，降水および蒸発散水の水質（污濁負荷濃度）は 0 と考えてよいものとする.

このような式は $n \times m$ 個あり, 水質 $p_{i}^{r}$ は, 水資源 連関表の各值 $x_{i j}^{r s} \cdot v_{j}^{r} \cdot g_{i}^{r} \cdot X_{i}^{r}$, 対象地域外加らの流入水 質 $r_{i}^{r}$, 污濁負荷流達率 $e_{i}^{r}$ および発生污濁負荷濃度 $q_{i}^{r}$ が 与えら机る上，こ机らの連立方程式の解として求められ る.これを行列表示すると，

$$
p=(X-f-t x e)^{-1}(v r+X q)
$$

となる。ここに，

$$
\begin{aligned}
& \boldsymbol{x}=\left[\begin{array}{l:l}
x_{11}^{11} & x_{12}^{11} \cdots \cdots \cdots x_{11}^{12} \\
x_{21}^{11} & x_{2 !}^{11} \\
& \\
x_{11}^{21} &
\end{array}\right]
\end{aligned}
$$

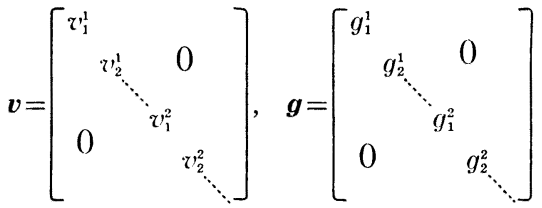

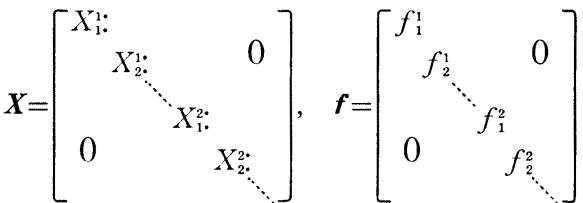

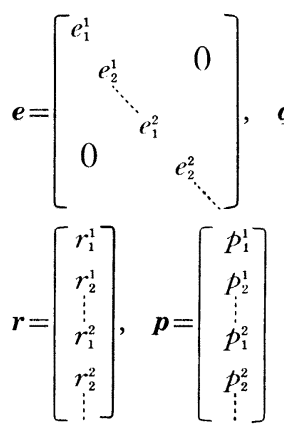

である。

各要素の水質は上記のようにして求まるが，特に河川 水質のみを問題にする場合には，次の制約条件式を考え ればよい。

$$
\begin{aligned}
& r_{1}^{r} v_{1}^{r}+\sum_{s=1}^{n} p_{1}^{s} e_{1}^{s} x_{11}^{s r}+p_{2}^{r} e_{2}^{r} x_{21}^{r r}+p_{7}^{r} e_{7}^{r} x_{71}^{r r}+p_{8}^{r} e_{8}^{r} x_{81}^{r r} \\
& \quad+p_{9}^{r} e_{9}^{r} x_{19}^{r r} \leqq \bar{p}_{1}^{r}\left(x_{13}^{r r}+x_{16}^{r r}+x_{17}^{r r}\right. \\
& \left.\quad+\sum_{s=1}^{n} x_{11}^{r s}+g_{1}^{r}\right)(r=1, \cdots, n) \quad \cdots \cdots \cdots \cdots \cdots(18
\end{aligned}
$$

ここに， $\bar{p}_{1}^{r}$ は地区 $r$ の河川に対する水質基準である. この制約条件を用いる際には水質值 $r_{1}^{r}, p_{1}^{s}, p_{2}^{r}, p_{2}^{r}, p_{8}^{r}$, および $p_{9}^{r}$, および污濁負荷流達率 $e_{j}^{r}$ を前もって評価 しておかなければならない，ところが，上流からの河川 水質 $p_{1}^{s}$ がその流量 $x_{11}^{s r}$ とともに末知数であり,式(18) は非線形となる. そこで, 本研究では全体的な精度のバ ランスや解析上の簡便さを考慮して, 式 (18) の $p_{1}^{s}$ (上
流から流入する河川水の水質）を $\bar{p}_{1}^{s}$ あるいは想定水 質でおきかえることにより線形化する方法, (2) 最適化 計算においては, この制約を除外し, 得られた結果を用 いて式（17）（非線形式）により水質を計算して水質基 準值を満しているかどらかをチェックする方法を併用す る.なお, 後述のケース・スタディーでは BOD につい てのみ考慮し, 水質污濁問題が厳しい場合には (1) の方 法でまずシミュレートし，(2) の方法でチェックを行う ことにした.

(8) 地下水取水量に関する制約

地盤沈下や地下水保全の観点から, 地下水取水量は制 限されることがある.

$$
\begin{array}{r}
x_{2 i}^{r r} \leqq \bar{x}_{2 i}^{r r} \text { または } \sum_{i=3}^{7} x_{2 i}^{r r} \leqq \bar{x}_{2 \cdot}^{r r} \cdots \cdots \\
\quad(i=3,4,5,6,7 ; r=1, \cdots, n)
\end{array}
$$

ここに, $\bar{x}_{2 i}^{r r}$ および $\bar{x}_{2}^{r r}$ は, それぞれ各地区の各要素お よび各地区全体に対して定められた許容地下水取水量で ある・

(9) 維持流量

河川流量は, 環境保全等の面からある一定量 $\left(\bar{x}_{11}^{r s} お\right.$ よび $\left.\bar{g}_{1}^{r}\right)$ を越えることが望まれている.

$$
\begin{array}{r}
x_{11}^{r s} \geqq \bar{x}_{11}^{r s} \text { および } g_{1}^{r} \geqq \bar{g}_{1}^{r} \cdots \cdots \cdots \cdots \\
\quad(r, s=1, \cdots, n \text { ただし } r \neq s)
\end{array}
$$

ところで一年間のトータル量を取り扱う場合には $\bar{x}_{11}^{r s} お$ よび $\bar{g}_{1}^{r}$ としては, 通常の意味での維持流量に洪水時に 利用されることなく流下する量を加えた值を与える必要 がある・

（v）技術・施設面からの制約条件

(10) 再利用水に関する制約

工業・家庭・業務の内部において循環再利用に回しう る水量は, 技術的な制約等から全使用水量のらちの一部 に限定される． $z_{j}$ を循環再利用率の上限とすれば,

$$
\begin{array}{r}
x_{j j}^{r r} /\left(x_{1 j}^{r r}+x_{2 j}^{r r}+x_{3 j}^{r r}+x_{j j}^{r r}+x_{8 j}^{r r}\right) \leqq z_{j} \\
\quad(j=4,5,6 ; r=1, \cdots, n) \cdots \cdots . .
\end{array}
$$

となる. また, 再生水の使用用途には衛生上その他の理 由により制限されることが多い， $g_{j}$ を全使用水に対す る再生利用率の上限とすれば, 次式を得る.

$$
\begin{aligned}
& \left(x_{j j}^{r r}+x_{8 j}^{r r}\right) /\left(x_{1 j}^{r r}+x_{2 j}^{r r}+x_{3 j}^{r r}\right. \\
& \left.+x_{j j}^{r r}+x_{8 j}^{r r}\right) \leqq g_{j} \cdots \cdots \cdots \cdots \cdots \\
& \quad(j=4,5,6 ; r=1, \cdots, n)
\end{aligned}
$$

(11) 利水施設により定まる河川取水可能量の上限

ダム等の利水施設の状態により, 河川から取水しらる 水量の上限が決定される.これは, 洪水時等に利用され ることなく河川を通過する水量を除いた利用可能水量の 上限を示す式であり，物理的な制約と考えてもよい.

$$
x_{13}^{r r}+x_{16}^{r r}+x_{17}^{r r} \leqq \bar{s}_{1}^{r}
$$


(12. その他

その他の制約も必要に応じて考虑する必要があり, 線 形表示されてモデルに組み込まれる．現実の問題に即応 した制約条件を多く設定すれば，得られる解は現実的で あり，実現の容易なものとなることが多い，一方，一部 の制約条件を取り上げなかったりするとその実現は容易 でない反面，問題の特性を把握する上で都合のよい場合 もある。

\section{b) 目的関数}

上述したような制約条件式を用いていえることは，す べての制約を満たす解が存在するか否か，存在するとす ればどの範囲であるかといらことである。ここでいう目 的関数は，これらすべての制約を満たす計画案のうち, なんらかの目的を定めることにより，その目的を最も満 たすものを採用するために用いられる。

目的関数としては種々のものが考えられる.

(1) 建設費および運営費を最小にする.

$$
\min \left\{\sum_{r=1}^{n} C^{r}\right\}
$$

(2) 水資源からみた対象地域への収容可能人口を最大 にする.

$$
\max \sum_{r=1}^{n} P^{r}
$$

(3) 水資源からみた対象地域における生産可能高を最 大にする.

$$
\max \sum_{r=1}^{n} O_{i}^{r}(i=5,6,7)
$$

(4) ウェイトゔけした目的関数を最大にする.

$$
\begin{array}{r}
\max \left[W_{1} \cdot\left(\sum_{r=1}^{n} P^{r}\right)+W_{2} \cdot\left(\sum_{r=1}^{n} O_{i}^{r}\right)\right. \\
\left.-W_{3} \cdot\left\{\sum_{r=1}^{n}\left(C^{r}+M^{r}\right)\right\}\right] \ldots \ldots \ldots . . .
\end{array}
$$

(5) その他

その他, 目的に応じて関数（線形表示された関数）が 設定される。

線形計画モデルの目的関数としては, 分析目的に応じ てこれらの中から適切なものを一つ選ぶことになる。こ のうち (1) は水資源の利用による効用などを制約条件に 上り規定しておき，それに必要な費用を最小とする計画 を求め上うとするものである。 また，(2) と (3) は水資源 の計画・管理のために支出しらる費用や他の効用などを 制約条件によって規定したらえで，特定の効果を最大化 しょうとするものである，その際，各目的（効用，不効 用）間のトレード・オフの関係は, 制約条件として示さ れる効用の必要水準や限界値を変化させた場合の目的関 数の值（目的達成度）の変化として把握される.また， 目的関数 (4)の上5に多目的に対して適正な水配分を考 える場合には,トレード・オフの関係にある複数の目的
の達成水準を考慮する目標計画法 (Goal Programming) や SWT (Surrogate Worth Trade-off) ${ }^{19}$ 法等を用い ることが可能であり，これについては次の機会に報告し たい。

\section{（3） 分解原理の適用による解法}

水資源問題の一つに（地区間特に上・下流地区間）の 利害関係汇関するものがある.この問題へのアプローチ のために, 本研究では分解原理の適用による解法 ${ }^{22)}$ 用した. 上述した水資源の配分問題に分解原理を適用す ると, 全体としての最適化の過程を, 各地区内部の最適 化をめざす複数の副問題と, 各地区相互間の調整により 流域全体としての最適化をめざす主問題に分けて把握す ることができ, 後述のよらに地区間の調整過程を明示的 に把握することが可能となる. 分解原理を水配分問題に 適用した場合の数学的構成と, その意義や利点について は参考文献 23) に詳述した。

\section{5. 大和川流域奈良盆地における ケース・スタディ}

ここでは 3.，4.で示した方法論を具体化するために， まず 表一2 の水資源連関表に沿って昭和 47 年度にお ける奈良盆地の水量収支を把握した. データは主として 昭和 47 年度のものを用いたが, 一部昭和 45 年度のも のも含まれている.

次に, 地域内に入る降水量と導水量が与えられた場合 に, 各種観点からみてどのように水を配分するのが合理 的であるかを検討するための最適配分モデルを作成し， 奈良盆地適用した.ここでは現況（昭和 47 年度）の 水配分と適正な水配分とを比較するために昭和 47 年度 の諸状態を前提として最適化を行った。

対象とした奈良県内の大和川流域を 図一3 に示す. この地域は県内の都市活動, 工業活動および農業活動の 中心地であり， 25 の市町村から構成されている.この うち, 奈良市, 天理市, 御所市および吉野郡大淀町の面 積のらちそれぞれ $42.1 \%, 19.1 \%, 7.5 \%, 76.8 \%$ は対 象地域外にある.

この地域では地表水と地下水の水文流域がほぼ一致し ており, 大体王寺町藤井の 1 か所から対象地域外一の流 出があるとみることができる，したがって，水量収支の 把握がなされやすい地域とされている.

水利用現況の特徴としては, 河川取水量の大半が農業 用水として使われていることがあげられる．また，下水 道施設は奈良市と橿原市の一部で整備されているだけで あり, 河川水質は悪く, 上・工水はその多くを地下水に 依存している. 


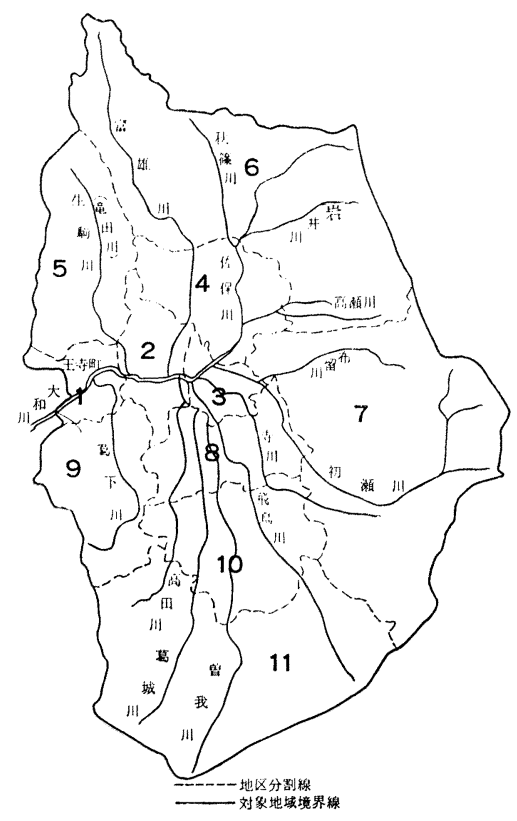

図一3 対象地域（大和川流域奈良盆地）と地区分割

諸活動の発展が著しいこの地域では, 水資源開発計画 や流域下水道整備計画が進められている.

\section{（1）流域構成要素}

流域構成要素としては，3．で示したものを考慮した. なお, 他地域から導水する場合には, それぞれの要素 （上水道・農業）を直接介して行われるとして取り报っ た.

\section{（2）地区分割}

本研究では，3.(3)b）で述べたことに注意し, 図一3
のように地区割りを行った。

\section{（3）水資源連関表による現状把握}

3. で述べた水資源連関表を奈良盆地で作成するにあ たり, 次のようなこの地域の特徴を考慮した. まず, こ の地域は地下水も含めて水文学的に閉じているとみるこ とができるために, 図一3で決定した地区のうち第 1 地 区からの河川流出を除いて地域外への流出はない.すな わち, すべての地区で対象地域外からの河川水・地下水 の流入 $\left(v_{1}^{r}, v_{2}^{r}\right)$, および地域外への地下水の流出 $\left(g_{2}^{r}\right)$ は ないと考えてよい. 農水は主として吉野川水系から分水 を受けており, 流域外一の分水 $\left(g_{7}^{r}\right)$ は行っていないと 考えられる. 奈良市と橿原市を除けば下水道施設はな く, 対象流域外との水のやりとり $\left(v_{8}^{r}, g_{8}^{r}\right)$ はもちろんな い. なお, 降水の河川への流入 $\left(u_{1}^{r}\right)$ および河川水の蒸 発 $\left(f_{1}^{r}\right)$ は, 「流域」要素を介して行われるとして取り 扱った.

水資源連関表による現状把握作業は, データの都合に より, 2 つのグループに分けて行った. すなわち, 市町 村別に収集されている上下水道関係の資料については, まず市町村別の連関表を作成し, その後, 先の地区割り に組みかえた. 河川水・地下水の地区間移動量や河川 水・地下水の地区内でのやりとり量等の水文量について は, 地区分割に沿って現状を把握した。表一4に昭和 47 年度の水資源連関表の 1 部分（地区 1 について）を 示す. また, 図-4 は, 作成した連関表をもとにして, 地区間を移動する水量を輸送機能をもつ要素別に表示し たものの例である. なお, 水資源連関表は, 地区数を $n$ とすれば, $n \times n$ 個の部分行列からなるが, 地区間の水 のやりとりを図一4 のように表示すれば, 必要な部分

表一4 水資源連関表による地区内水収支現況の表示例（地区 1 について）

\begin{tabular}{|c|c|c|c|c|c|c|c|c|c|c|c|c|c|}
\hline \multirow{2}{*}{\multicolumn{2}{|c|}{ 流入 }} & \multirow{2}{*}{1 河川 } & \multirow{2}{*}{2 地下 } & \multirow{2}{*}{3 上水道 } & \multirow{2}{*}{4 家庭 } & \multirow{2}{*}{5 業務 } & \multirow{2}{*}{6 工業 } & \multirow{2}{*}{7 農業 } & \multirow{2}{*}{8 下水道 } & \multirow{2}{*}{9 流域 } & \multirow{2}{*}{$\begin{array}{l}\text { 他地区同 } \\
\text { 要素 }\end{array}$} & \multicolumn{2}{|c|}{ 系 外 } \\
\hline & & & & & & & & & & & & $g$ 地域外 & $f$ 蒸発散 \\
\hline 1 河 & 川 & - & - & - & - & - & - & 2209 & - & - & - & 641233 & - \\
\hline 2地 & 也 $\quad 下$ & 31498 & - & 2423 & 10 & 1 & 821 & 116 & - & - & 0 & - & - \\
\hline 3 上 & 水 道 & - & 590 & - & 1639 & 218 & 141 & - & - & - & - & - & - \\
\hline 4 家 & 庭 & - & - & - & - & - & - & - & - & 1451 & - & - & 198 \\
\hline 5 業 & 務 & - & - & - & - & - & - & - & - & 193 & - & - & 26 \\
\hline $6 I$ & 業 & - & - & - & - & - & 60 & - & - & 817 & - & - & 145 \\
\hline 7 展 & 業 & 1760 & 1737 & - & - & - & - & - & - & - & - & - & 1737 \\
\hline & 水 道 & - & - & - & - & - & - & - & - & - & - & - & - \\
\hline 9 济 & i 域 & 9139 & 2862 & 165 & - & - & - & - & - & - & - & - & 9540 \\
\hline & $\begin{array}{ll}\text { 地 } & \text { 同 } \\
\text { 素古 } & \vdots\end{array}$ & $\begin{array}{l}\text { (2)加ら } \\
558699 \\
\text { (9)加 } \\
42346 \\
\end{array}$ & $\begin{array}{c}\text { (5) 加 } \\
9487 \\
\text { (9) 品 } \\
20193 \\
\end{array}$ & - & -- & - & - & - & - & - & - & - & - \\
\hline 系 & $v$ 地域外 & - & - & - & -- & - & - & 184 & - & - & - & - & - \\
\hline 外 & $u$ 降 水 & - & - & - & - & - & - & 2725 & - & 19245 & - & - & - \\
\hline
\end{tabular}

（注）横線は，この地区では水のやりとりが考えられないルートを示す。 


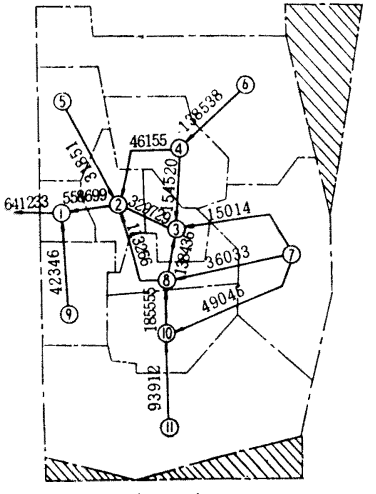

(河 川)

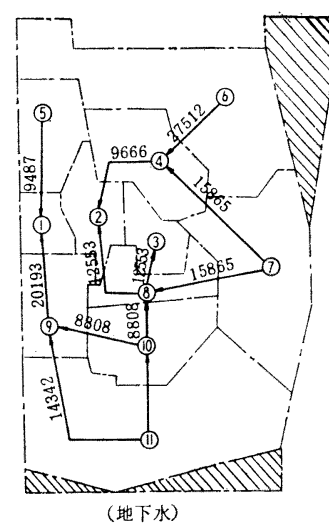

图一4地区間を移動する水の収支現況（河川水および 地下水についての表示例)

行列は $n$ 個となる。

現況把握を行う際に, 統計資料によっては入手が容易 でないものもあり, 特に「農業」「流域」要素に対して は困難を伴い, 種々の仮定を設けることにより, その值 を推定した ${ }^{23)}$.

\section{（4）大和川流域奈良盆地における水資源の配分・利 用モデルの基本構造}

前述の水資源配分・利用モデルは次のようにして現実 の問題に適用される. まず, 地区内（同一地区内の要素 閒）および地区間の水配分ルートを設定する必要があ る.これは，現状把握の結果および将来の施設㖕画から モデル化した．各地区内部の配分ルートは，表一2の A，D等で示されているとおりである。地間の水のや りとりは, 流域を構成する 9 要素のうちの 5 要素（河 川・地下・上水道・農業・下水道）を通じて行われる が，奈良盆地では，図一5 にマトリックス表示したルー トで水の地区間移動が起こりらるとして, 各要素の地区 間ルートを設定した. また, 今回のシミュレーションで は, 表一3 に示される諸係数および河川水・地下水の分

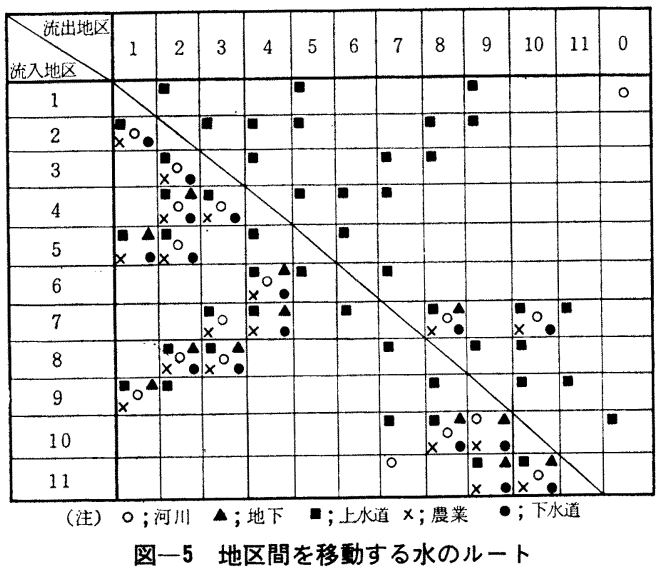

流比は現状の值を用いた．河川水・地下水の移動方向 は，河床勾配，等地下水線からそれぞれ決定した。

本モデルは，対象地域外および系外から受けとる水を 対象地域内の各地区各要素へ適正配分するためのもので あり, 地域の降水量および他の地域とのやりとり量（流 出・入量）は外生的に与えられる。ここでは昭和 47 年 度の值をそのまま与えた. 本モデルでは, 多数の係数や 制限值 (定数) を設定する必要があるが設定の際の考え 方や採用した値については参考文献 23) を参照された W.

なお, 本モデルは変数 529 , 制約条件式 489 （地区内 変数のみからなる制約条件式 374 , 地区間変数を含む制 約条件式 115）から構成される ${ }^{23)}$.

\section{（5）計算結果および考察}

適正水配分シミュレーションは，3つの目的関数に対 して行った. 目的関数の第 1 (ケースI) は流域全体の 水資源配分に関する総経費 (式 (24)) を最小にするもの であり，第 2 (ケースII）は水資源から見た収容可能人 口(式 (25)) を最大にする，また，第 3 (ケースIII) は 同じく工業産出可能高（式（26）で $i=6$ ）を最大にす るものである.
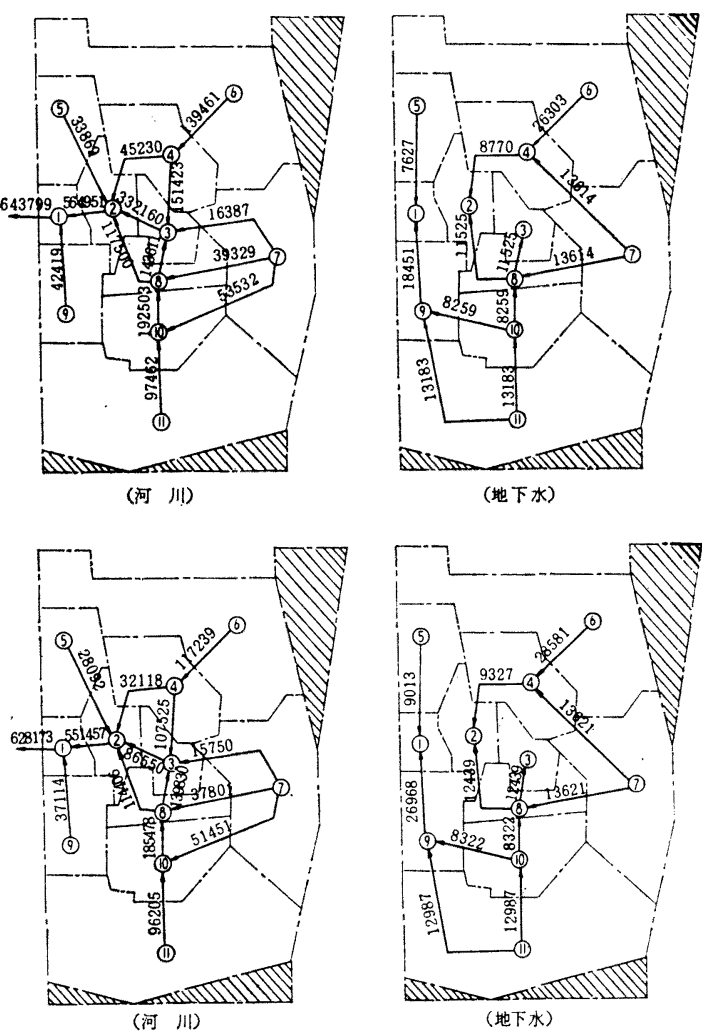

（注）上段はケースI，下段はケースIIの場合

図一6地区間を移動する水の適正配分状況（河川水および 地下水についての表示例) 
表一5 地区内を移動する水の適正配分状況の表示例（地区 1 について）

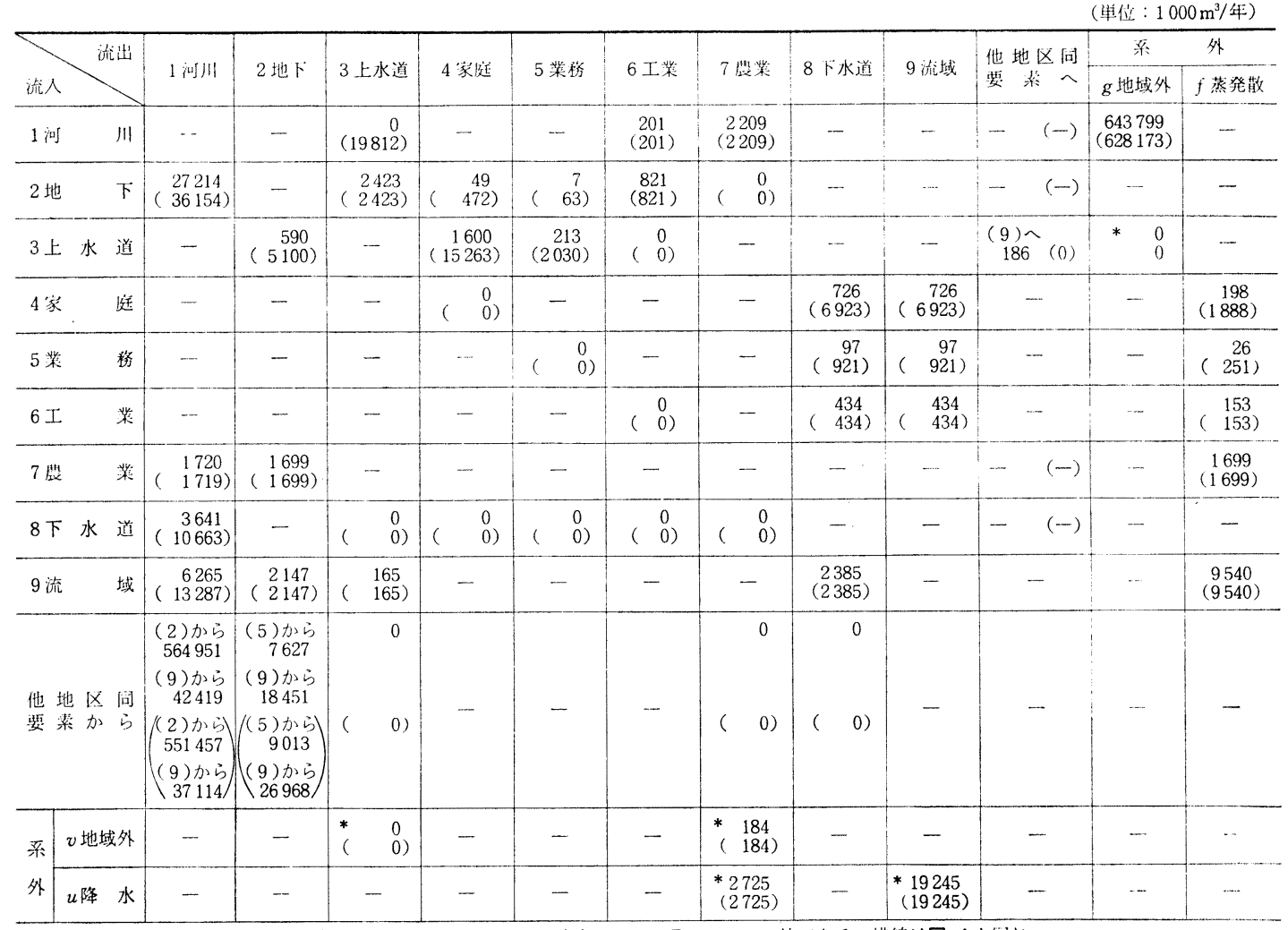

（注） *印は外生変数を示す。表中で（）なしはケースI，（）内はケースIについての值である。横線は図-4之闰じ

その結果の一部を，現状把握に関する 表一4, 図一4 と同様の形式で 表一5, 図一6 に示す. 現状の水資源連 関表とここで得られた結果を比較することにより，流域 に内在する水資源をめぐる諸問題を検討することが吤能 である.

今回のシミュレーションから得られたおもな結論は次 のとおりである.

（1）最適化計算において分解原理を用いることによ り, 実行可能領域内での流域全体の最適化を, 地区内部 の最適化と地区間の調整過程としてとらえることができ る. 解の改良を行うステップ回数にしたがって, 目的関 数がいかに変化していくかを図一7 に示す．同図で目 的関数が急変するところは地区間変数が基底に取り込ま れ，解の改良が行わ机たこころであり，ここで考えてい るような水配分計画では, 地区間の調整が結果に大きな 影響をもたらすことを意味している.

（2）総経費を最小にする目的関数のもとでは，制約 を満たす際に最も経費りかからない方法が上られる。シ ミュレーションの結果は, 現状把握で得られたものし類 似している. したがって, 徉来の利水方式が総経費最小 の方向性をもっていたと考えることもできよう．な拀， 計算の結果得られた総経費は現状の約 3 割減であり, 費

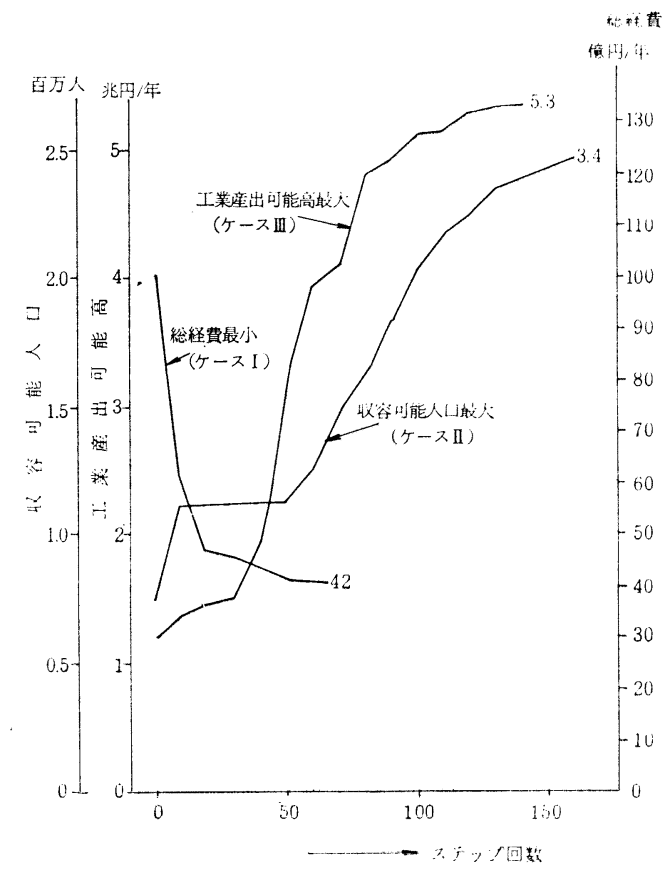

図-7 目的関数值の変化 
用の面からも水配分合理化の余地があると考えられる.

（3）第 2 の目的関数のもとでは，1人あたりの水使 用量が少ない地区の人口収容能力が相対的に増大する. シミュレーションの結果は，この地域では水資源に関す る投資可能限度額を増すと，水資源からみた収容可能人 口が急増することを示している.

（4）第 3 の目的関数のもとでは，（3）と同様に, すべての制約をみたしてまだ残っている水が，まず工業 生産に対する水量原単位の小さな地区に与えられ，その 地区の負担可能な費用の上限に達するまで水を使うと， 次に原単位の小さな地区に水が割りあてられる.この場 合には, 上水・農水・下水の地区間移動が活発になる. これは, 主として水量原単位の小さな地区での生産を増 すことにより，地域全体としてより大きな利益を得よう とするためである. ケースII と同様に，投資可能限度額 の増加とともに産出可能高は急増する.

（5）さらに感度分析の一例（図一8 参照）でみるよ らに，ケースIIIでは各地区が負担しらる水資源に関連し た費用が増加するほど, ますます原単位の小さな地区に 水が集中する. その結果, 原単位の小さな地区と大きな 地区の産出可能高の格差が増大寸る.このことは，第 2 の目的関数の場合にも同様である.

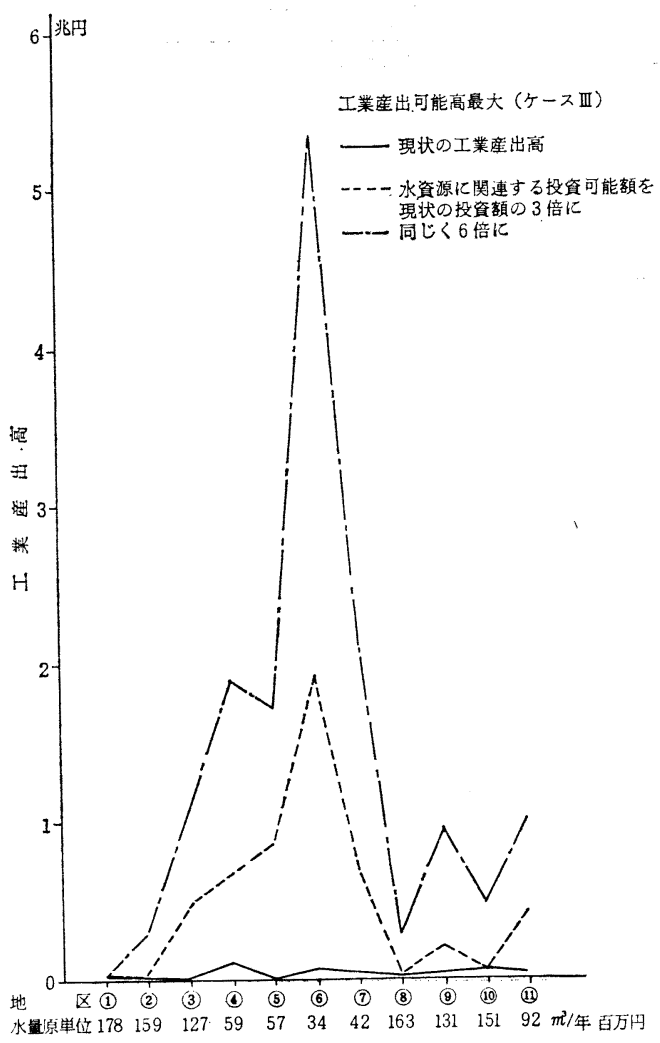

図一8 水配分に関する負担可能な費用を 変化させたときの感度分析
（6）第 $2 ， 3$ の目的関数を設定して行ったシミュレ ーション結果より，今回対象とした大和川流域では，水 資源からみた地域の開発・発展の可能性は十分大きいと 考えられる。

（7）今回用いたような線形モデルでは, 諸係数（定 数）のうちあるもの（たとえば投資可能限度額）は結果 に大きな影響を及ぼすことがある，同様に，制約条件の 与え方により結果が大きく変化することもある. 一般 に，このような最適化問題において現実的な解が得られ るかどうかは，制約式の設定と諸係数 (定数) の与え方 いかんによる。

（8）今回のシミュレーションは，あくまで水資源の 面からみたものであり, 結果の解釈においては,この前 提を忘れてはならない. 水配分計画立案の際には, シミ ュレーション結果と地域社会の関倸等を多角的に検討 し, 土地や経済・制度等の面からの制約をはじめとする 多くのフィージビリティ・チェックとそれに伴うモデル の修正を行う必要がある.

\section{6. 結論}

本研究の成果と今後の課題は次のとおりである.

（1）流域における水収支の総合的な把握方法とし て, 水資源連関表を提案した. 現状ではデータの入手の 困難さからいくつかの仮式を必要とするが，このような 水量収支のとらえ方は可能であり, 各地区の総流入量, 総流出量, 水利用量, 水利用率, 河川取水量などを把握 することができる。

（2）水資源の配分・利用問題を, 上記の水量収支の とらえ方に基づいて定式化した. 解法の手段として分解 原理を用い，最適化の過程を地区間と各地区内部の調整 としてとらえた.

（3）大和川流域奈良盆地でケース・スタディを行 い，(1)，(2）の方法を具体化した.

(4) 今回のケース・スタディにおける現状把握で は, 水資源連関表の適用性の検討を行うとともに, 現存 する資料や解析法により，流域の水収支を現在やりうる 精度で総合的に把握して，今後の水資源に関する調査・ 研究のあり方を明確にすることも一つの目的とした。 そ の結果として，大和川流域奈良盆地に関しては「農水」 や「流域」要素に関する資料が不足しているように思わ れた。 また，直接測定されてないデー夕は解析法等を用 いて推定する必要があるが，その手法も水文量によって 精度がまちまちである. 総合的な流水の管理を行らため には，全体としてバランスのとれた観測や解析法の開発 を行うべきであると考えられる。

（5）本研究では水収支を年間のトータル量で上らえ 
たが，今後は流域に入ってくる水量や水利用状況の季節 変動を考虑した任意の期間を対象にした手法の開発が必 要である. そのような場合の状況把握では, 前述のよう に流域構成要素における貯留（ストック）を考慮する必 要があり，今回示したやりとり量（フロー量）に対する 水資源連関表を抬張して用いることが可能である.

（6）今回提案した方法を有効に用いるためには, 従 来, 河川に関して収集されてきた情報（資料）のみでな く, 広く経済・社会・環境等の地域社会の情報を必要と する.したがって，流域の水管理を総合的に行うために も, 地域データ・バンク・システム ${ }^{21)}$ 整備が望まれ る.

謝辞：本研究を進めるにあたっては, 建設省近畿 地方建設局企画部から資料の提供をうけ，本論文をまと める際には東京工業大学 吉川教授・森地助教授をはじ め多くの方々から有益な情報を提供していただいた。ま た, 土木研究所 岩松システム課長から多くの助言を得 たことを記して，感謝の意を表します．

\section{参 考 文 献}

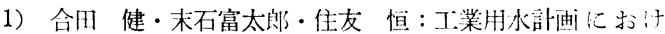

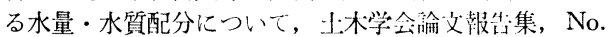
134,1966 年 10 月.

2) Heady, E.O. et al. : National and Interregional Models of Water Demand, Land Use and Agricultural Policies, Water Resources Research, Vol. 9, No. 4, August, 1973.

3) Reynolds, J.E. : Allocating Water among Alternative Uses, Journal of the Irrigation and Drainage Divi. sion, ASCE, Vol. 97, No. 1, March, 1971.

4) Меуитов, И.И., Гершковиу, М.И. : Олтимизация ислользования волных ресурсов в дефицитных ло воде бассейнах, Гидротех и Мелиорация, 19$12,1967$.

5) Фельдман, М.Л. : Олтимальное раслределение водных ресурсов между водолользователями и водолотребителями, Гидротехниуеское Строительство, No. 4, 1969.

6）春名 攻・岡出憲夫：公域利水に打ける水配分計画モデ ルに関する一考察，上木学会論文報告集，No. 211，1973 年 3 月.
7）吉川和広 - 岡田憲夫 : 広域的, 多角的な 水配分問題に 関 するシステム分析, 土木学会論文報告集, No. 239, 1975 年 7 月.

8）吉川和広・岡田憲夫：非線形計画モデルによる 1 水系流 域における広域的, 多角的水配分に関する一分析, 土木 学会論文報告集, No. 247,1976 年 3 月.

9）末石富太郎 : 用途別給水計画の研究, 水道協会雑誌, No. 436,1971 年 1 月.

10) Clyde, C.G. et al. : Optimal Allocation of Water Resources in Utah, Journal of the Hydraulic Division, ASCE, Vol. 99, No. 10, October, 1973.

11) Swanson, H.S. et al. : Optimization of Water Allocation Dicisions Affecting Estuarine Ecology, Water Resources Bulletin, Vol. 7, No. 4, August, 1971.

12) Bargur, J. : Dynamic Multisector Programming Approach to Regional Water Resource Management, Water Resources Research, Vol. 8, No. 4, August, 1972.

13）丹保憲仁 : 都市・地域水代謝システムの構造と容量一都 市用排水系の再評価のための研究 (I ), 水道協会雑誌, No. 497,1976 年 2 月.

14）本間 仁·石原藤次郎編：応用水理学下 II (p. 67), 丸 善, 1971 年.

15）建設省土木研究所：水資源の利用配分に関するシステム 分析，土木研究所資料，No. $1125 ， 1976$ 年 3 月.

16）高橋 甪-池田喜代治: 奈良県大和盆地の地下水, 地質 調查月報, Vol. 16, No. 7, 1965 年 6 月.

17）篗田 博：カンガイ用水が地下水に及ぼす影響について （その 1) 一大和平野に打ける地下水の実態，㕮業上木学 会誌, Vol. 33, No. 7, 1965 年 10 月.

18) Dantzig, G.B. et al. : The Decomposition Algorithm for Lincar Programming, Econometrica, Vol. 29, No. 4, October, 1961.

19) Haimes, Y.Y., et al. : Multiobjectives in Water Resource Systems Analysis; The Surrogate Worth Trade Off Method, Water Resources Research, Vol. 10, No. 4, August, 1974.

20）建設省近畿地方建設局企画部：都市排水 質的制御シス テムに関する調查報告書, 1975 年 3 月.

21）小池舆春・関 正和：電子計算機を活用した地域情報シ ステムの構想，上木技術資料，Vol. 18，No. 8，1976 位 8 月.

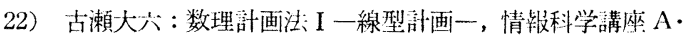
$3 \cdot 2$, 共立出版, 1971 年 6 月.

23）岩松・関・吉川・三好：流域における水循環の把握と水 資源の配分に関する研究 (I)，土木研究所報告,第 149 劣, 1977 年 9 月.

(1977.2.22 • 受付) 